\title{
Socio Economic Characteristic of Dryland Farmers in Tiruppur District, India-A Gender Analysis
}

\author{
P. Sindhuja* and M. Asokhan \\ Department of AE \& RS, TNAU, Tamil Nadu, India \\ *Corresponding author
}

\section{A B S T R A C T}

\begin{tabular}{|l|}
\hline Ke y w o r d s \\
Gender, Dryland \\
$\begin{array}{l}\text { Farming system, } \\
\text { Socio-economic } \\
\text { characteristic }\end{array}$ \\
\hline Article Info \\
\hline $\begin{array}{l}\text { Accepted: } \\
\text { 04 February } 2018 \\
\text { Available Online: } \\
\text { 10 March } 2018\end{array}$ \\
\hline
\end{tabular}

A study was taken up among the farmers in the Tiruppur district to assess the determinants of gender in farming in dryland farming system. Totally three blocks were selected Purposively for the study in Tiruppur district of Tamil Nadu, The block such as Palladam, Pongallur, Kundadam have been selected. A sample of 30 land holding dryland farm women and 30 farm men from each block was purposefully selected. Thus the total sample size is 180 . The study reveals that gender activities in dryland farming shows significant changes but not in level they possessed except in few like Educational status where 38.89 per cent of male farmers are educated up to secondary level and nearly more than half of the female respondent $(53.33 \%)$ are illiterate.

\section{Introduction}

In India Drylands are typically characterized by low annual rainfall (300-750 $\mathrm{mm}$ per annum) and higher potential evapotranspiration (PET). In India, 68\% of the total net sown area comes under dry land cultivation, spread over 177 districts. Most dry land areas in India have more than 7 months rainless period with essentially no or very little precipitation. In certain areas the total annual rainfall does not exceed $500 \mathrm{~mm}$ (Guhathakurta and Rajeevan, 2008).

In this criteria it is difficult for the farmers to maintain desired socio economic status, so this study aims to discover the socio economic characteristic possess by dryland farmers especially dryland farmer based on their gender whom facing difficulties to sustain their livelihood status is seen.

\section{Materials and Methods}

Tiruppur district of Tamil Nadu was purposively selected for study because it is one of the districts where the percentage of rainfall is minimum for past ten years. Pongalur, Palladam, Kundadam blocks were selected based on the highest unirrigated area. Based on this thirty farm women and thirty farm men holding land from each block was 
selected and comprises total sample size of 180. Data collection was done with the use of a semi -structured and pre-tested interview schedule. The data were collected by personally interviewing the respondents. Necessary effort was made to check and cross check the data collected from the respondents. The statistical tool used in this study was simple percentage analysis. Percentage analysis was used in descriptive analysis for making simple comparisons.

\section{Results and Discussion}

The socio economic characteristics of dryland farm women and farm men practicing farming in dryland farming system are given in Table 1.

\section{Age}

Age is operationalized as year of life activity spend by farm women and farm men in Dryland farming system. The overall analysis reveals that 66.7 per cent of farmers belong to old age where 73.34 per cent male farmers and 60.00 per cent female farmers belong to old age. The reason behind this is the sampled farmers are land owned farmers and doing dry farming over a long period.

\section{Educational status}

Education status is operationalized as the degree of knowledge possessed by the respondents through education system, from the result it is clear that 42.80 per cent of respondent are illiterate in total, regarding comparison 38.89 per cent of male farmers are educated up to secondary level i.e. Completed schooling education and nearly more than half of the female respondent $(53.33 \%)$ are illiterate. The reason is that the women farmers are highly custom bounded and given with high family responsibilities and not allowed to go school.

\section{Occupation}

Occupation is operationalized as work performed by the respondent to earn income. From the result it is clear that majority (93.9\%) of the farmer doing farming alone. In comparison 5.55 per cent women farmer concentrate only on farming because the women farmers are land owned and occupied with farming in their own land.

\section{Farm size}

Farm size is operationalized as the farm holding possess by the respondents, The result reveals that 51.7 per cent of farmers possessed more than five acres of land and in comparison female gender shows 3.33 per cent higher possession because in farm homes land is registered in female name for safety purpose and also female respondents of old aged possessing land in their names which comes after death of their husbands.

\section{Farming experience}

Farming experience is operationalized as number of years respondent continuing farming.

Result reveals 57.8 per cent of farmers have high experience and in comparison 2.22 farm women show increase in experience because it correlate with farming size and occupation possessed with gender and also because farmers are high in old age category.

\section{Annual income}

Income earned by respondent in the year is conceptualized as annual income. Table shows farmers possess low (47.8\%) income.

The farmers in dryland suffer from drought for past three years this is the reason for low income of the farmers. 
Table.1 Socio economic characteristics of dryland farm women and farm men

\begin{tabular}{|c|c|c|c|c|c|c|c|c|}
\hline \multirow[t]{2}{*}{$\begin{array}{l}\text { SI. } \\
\text { No. }\end{array}$} & \multirow[t]{2}{*}{$\begin{array}{l}\text { Profile of the } \\
\text { respondent }\end{array}$} & \multirow[t]{2}{*}{ categories } & \multicolumn{2}{|c|}{$\begin{array}{l}\text { Male } \\
\text { farmers }(n=90)\end{array}$} & \multicolumn{2}{|c|}{$\begin{array}{l}\text { Female } \\
\text { farmers }(n=90)\end{array}$} & \multicolumn{2}{|c|}{ Total $(n=180)$} \\
\hline & & & No. & $\%$ & No. & $\%$ & No. & $\%$ \\
\hline \multirow[t]{3}{*}{1} & Age & Young & 2 & 2.22 & 2 & 2.22 & 4 & 2.2 \\
\hline & & Middle & 22 & 24.44 & 34 & 37.78 & 56 & 31.1 \\
\hline & & Old & 66 & 73.34 & 54 & 60.0 & 120 & 66.7 \\
\hline \multirow[t]{8}{*}{2} & Educational status & Illiterate & 29 & 32.22 & 48 & 53.33 & 77 & 42.8 \\
\hline & & $\begin{array}{l}\text { Functionally } \\
\text { literate }\end{array}$ & 4 & 4.44 & 1 & 1.11 & 5 & 2.8 \\
\hline & & $\begin{array}{l}\text { Primary } \\
\text { education }\end{array}$ & 8 & 8.89 & 2 & 2.22 & 10 & 5.6 \\
\hline & & $\begin{array}{l}\text { Middle } \\
\text { education }\end{array}$ & 5 & 5.55 & 4 & 4.44 & 9 & 5.0 \\
\hline & & $\begin{array}{l}\text { Secondary } \\
\text { education }\end{array}$ & 35 & 38.89 & 30 & 33.33 & 65 & 36.0 \\
\hline & & Diplamo & 2 & 2.22 & 0 & 0 & 2 & 1.1 \\
\hline & & Under graduate & 4 & 4.44 & 5 & 5.55 & 9 & 5.0 \\
\hline & & Post graduate & 3 & 3.33 & 0 & 0 & 3 & 1.7 \\
\hline \multirow[t]{4}{*}{3} & Occupation & Wage earner & 2 & 2.22 & 0 & 0 & 2 & 1.1 \\
\hline & & Farming alone & 82 & 91.11 & 87 & 96.66 & 169 & 93.9 \\
\hline & & $\begin{array}{l}\text { Farming with } \\
\text { wage earner }\end{array}$ & 4 & 4.44 & 3 & 3.33 & 7 & 3.9 \\
\hline & & Private job & 2 & 2.22 & 0 & 0 & 2 & 1.1 \\
\hline \multirow[t]{2}{*}{4} & Farm size & Small farmer & 45 & 50 & 42 & 46.67 & 87 & 48.3 \\
\hline & & Big farmer & 45 & 50 & 48 & 53.33 & 93 & 51.7 \\
\hline \multirow[t]{3}{*}{5} & $\begin{array}{l}\text { Farming } \\
\text { experience }\end{array}$ & Low & 6 & 6.67 & 12 & 13.33 & 18 & 10.0 \\
\hline & & Medium & 33 & 36.67 & 25 & 27.78 & 58 & 32.2 \\
\hline & & High & 51 & 56.67 & 53 & 58.89 & 104 & 57.8 \\
\hline \multirow[t]{3}{*}{6} & Annual income & Low & 36 & 40 & 50 & 55.55 & 86 & 47.7 \\
\hline & & Medium & 22 & 24.44 & 26 & 28.89 & 48 & 26.7 \\
\hline & & High & 32 & 35.55 & 14 & 15.55 & 46 & 25.6 \\
\hline \multirow[t]{2}{*}{7} & Material possesion & possessed & 70 & 77.78 & 51 & 56.67 & 113 & 62.78 \\
\hline & & Not possessed & 20 & 22.22 & 39 & 43.33 & 67 & 37.22 \\
\hline \multirow[t]{3}{*}{8} & $\begin{array}{l}\text { Social } \\
\text { participation }\end{array}$ & Low & 0 & 0 & 0 & 0 & 0 & 0 \\
\hline & & Medium & 83 & 92.22 & 83 & 92.22 & 166 & 92.2 \\
\hline & & High & 7 & 7.78 & 7 & 7.78 & 14 & 7.7 \\
\hline \multirow[t]{3}{*}{9} & $\begin{array}{l}\text { Leadership } \\
\text { behavior }\end{array}$ & Low & 0 & 0 & 0 & 0 & 0 & 0 \\
\hline & & Medium & 12 & 13.33 & 14 & 15.56 & 26 & 14.4 \\
\hline & & high & 78 & 86.67 & 76 & 84.45 & 154 & 85.6 \\
\hline 10 & Credit orientation & Low & 17 & 18.89 & 19 & 21.11 & 36 & 20.0 \\
\hline
\end{tabular}




\begin{tabular}{|c|c|c|c|c|c|c|c|c|}
\hline & & Medium & 73 & 81.11 & 71 & 78.89 & 144 & 80.0 \\
\hline & & high & 0 & 0 & 0 & 0 & 0 & 0 \\
\hline \multirow[t]{3}{*}{11} & $\begin{array}{l}\text { Scientific } \\
\text { orientation }\end{array}$ & Low & 8 & 8.89 & 8 & 8.89 & 16 & 8.8 \\
\hline & & Medium & 17 & 18.89 & 20 & 22.22 & 37 & 20.6 \\
\hline & & high & 65 & 72.22 & 62 & 68.89 & 127 & 70.6 \\
\hline \multirow[t]{3}{*}{12} & $\begin{array}{l}\text { Economic } \\
\text { motivation }\end{array}$ & Low & 14 & 15.55 & 5 & 5.55 & 19 & 10.5 \\
\hline & & Medium & 6 & 6.67 & 3 & 3.33 & 9 & 5.0 \\
\hline & & high & 70 & 77.78 & 82 & 91.12 & 152 & 84.5 \\
\hline \multirow[t]{3}{*}{13} & Innovativeness & Low & 6 & 6.67 & 1 & 1.11 & 7 & 3.9 \\
\hline & & Medium & 26 & 28.89 & 35 & 38.89 & 61 & 33.9 \\
\hline & & high & 58 & 64.44 & 54 & 60 & 112 & 62.2 \\
\hline \multirow[t]{3}{*}{14} & $\begin{array}{l}\text { Contact with } \\
\text { extension agency }\end{array}$ & Never & 29 & 32.22 & 15 & 16.67 & 44 & 24.5 \\
\hline & & Occasionally & 55 & 61.11 & 73 & 81.11 & 128 & 71.1 \\
\hline & & Regularly & 6 & 6.67 & 2 & 2.22 & 8 & 4.4 \\
\hline \multirow[t]{3}{*}{15} & Risk orientation & Low & 40 & 44.45 & 40 & 44.45 & 80 & 44.4 \\
\hline & & Medium & 48 & 53.33 & 47 & 52.22 & 95 & 52.8 \\
\hline & & high & 2 & 2.22 & 3 & 3.33 & 5 & 2.8 \\
\hline \multirow[t]{3}{*}{16} & Exposure & Never & 58 & 64.45 & 56 & 62.22 & 114 & 63.3 \\
\hline & & Occasionally & 32 & 35.55 & 33 & 36.67 & 65 & 36.1 \\
\hline & & Regularly & 0 & 0 & 1 & 1.11 & 1 & 0.6 \\
\hline \multirow[t]{3}{*}{17} & Attitude & Low & 26 & 28.89 & 16 & 17.78 & 42 & 23.3 \\
\hline & & Medium & 8 & 8.89 & 11 & 12.22 & 19 & 10.6 \\
\hline & & high & 56 & 62.22 & 63 & 70.00 & 119 & 66.1 \\
\hline \multirow[t]{3}{*}{18} & $\begin{array}{l}\text { Marketing } \\
\text { behavior }\end{array}$ & Low & 24 & 26.67 & 29 & 32.22 & 53 & 49.0 \\
\hline & & Medium & 54 & 60.0 & 45 & 50.0 & 99 & 55.0 \\
\hline & & 1 & 12 & 33 & 16 & 17.78 & 28 & 26.0 \\
\hline
\end{tabular}

\section{Possession}

Possession is termed as holding held by the respondent it operationalized as household materials and farming implements possessed by the respondents. The table reveals that 62.78 respondent had possession in comparison 77.78 per cent of male farmers had possession and 52.22 per cent of female farmers lack possession. This is because the freebies given by the government has an important role in household possession and freebies given in family head names where men are the head of the farm families.

\section{Social participation}

Social participation is operationalized as involvement in societal activity where 92.2 per cent of the farmer shows medium level of participation because of old age and high experience in dryland farming system.

\section{Leadership behavior}

Leadership refers to ability of a person to influence people to co-operate in achieving a goal. With respect to gender, majority (85.60 $\%$ ) of the farmers possessed high leadership abilities. In comparison 2.22 per cent of farm 
men shows higher leadership because of high out world awareness compare to female farmers in dryland farming system.

\section{Credit and risk orientation}

Credit and risk orientation decides the degree of orientation to avail credit from credit institutions and degree of risk taken by the farmers to withstand in farming. The overall analysis reveals that 80.00 per cent and 52.8 per cent of the farmers have medium level credit and risk orientation respectively.

In comparison women possess 78.89 per cent and 52.22 per cent which is less than farm men $(81.11 \%, 53.33 \%)$ respectively. The reason behind this is that the women feel that credit makes them fall easy victim to local money lenders and leads them to be dependent on them also farm women leave their risk under husband view.

Scientific orientation, Economic motivation, innovativeness and attitude

Scientific orientation, Economic motivation, attitude and innovativeness contribute more hand-in-hand to the status and livelihood of the dryland farmers. From the table reveals the relation between the four factors where dryland farmers have high $(70.6 \%, 84.5 \%, 66.1 \%$, $62.2 \%$ ) orientations (Scientific orientation, Economic motivation, attitude and innovativeness) respectively. In comparison there is no differences in the level they possessed. This level of orientation might be the reason farmers continuing dryland farming still after recurrent drought occurs.

\section{Exposure to external sources}

63.33 per cent of the dryland farmers practicing dryland farming system show less exposure from external sources. In comparison both gender show less $(64.44 \%$ male and $62.22 \%$ female) exposure. The reason is that respondents are old aged and possessed more experience where they practiced from trial and error so they believed that knowledge possessed by them and peer farmers is sufficient for their development.

\section{Marketing behavior}

More than half $(55.00 \%)$ of the farmers possessed medium marketing behaviour.in comparison farm men possessed $10.00 \%$ higher marketing then female because of marketing done by male farmers. Even though the farmers are experienced the modern marketing technology shows constraints.

\section{References}

Rathore, S.S. and B.P. Bhatt. 2008. Productivity Improvement in Jhum Fields through Integrated Farming System. Indian Journal of Agronomy, 53(3): 167-171.

Reardon, T., P. Malton and C. Delgado. 1998. Coping with Household Level Food Insecurity in Drought Affected Areas of Burkina Faso. World Development, 16(9): 1065-1074.

Sujeetha, T.N., M. Anamica and Balarubini, M. 2017. Socio Economic Characteristics of Self Help Group Tribal Women in Nilgiris District, India. Int.J.Curr.Microbiol.App.Sci. $\quad 6(11)$ : 3988-3991.

\section{How to cite this article:}

Sindhuja, P. and Asokhan, M. 2018. Socio Economic Characteristic of Dryland Farmers in Tiruppur District, India - An Gender Analysis. Int.J.Curr.Microbiol.App.Sci. 7(03): 54-58. doi: https://doi.org/10.20546/ijcmas.2018.703.006 